\title{
Competing Agendas for Land-Use Around Airports
}

\author{
Fiona Rajé $\mathbb{D}^{\mathbb{D}}$, Delia Dimitriu, Dan Radulescu, Narcisa Burtea, \\ and Paul Hooper
}

\begin{abstract}
This chapter describes the core aspects of the land-use planning (LUP) element of the Balanced Approach (BA) by acknowledging the potential of effective LUP as one of the few anticipatory tools available to manage noise. It explores the planning shortcomings that fail to stop encroachment and, thus, the need for remedial mitigation actions such as sound insulation, compensation and buy-out. It goes on to outline core future challenges and steps to develop a better spatial understanding of noise through improved understanding of people's soundscapes (e.g. via the ANIMA app). To illustrate how LUP challenges can be addressed, the chapter also presents case studies from Iasi Airport and on insulation campaigns, in Marseille and Heathrow respectively. It concludes with an exploration of the lessons that can be taken from LUP experience and examines how more comprehensive communication and engagement with key stakeholders underpins more effective application of planning tools.
\end{abstract}

Keywords Land use planning $\cdot$ Encroachment $\cdot$ Balanced approach $\cdot$ Mitigation Planning tools $\cdot$ Preventive controls

\section{Introduction}

Regulatory responses to aircraft noise are influenced at the global level by the UN International Civil Aviation Organisation (ICAO), and specifically its 'Balanced Approach' to noise management, adopted at the ICAO 33rd Assembly on Aircraft noise in 2001 [17]. The rationale for the Balanced Approach was built on the concept that airports face their own specific circumstances in terms of levels of traffic, the volume of nighttime flights, proximity of the airport to residential areas, and attitudes

F. Rajé $(\bowtie) \cdot$ D. Dimitriu $\cdot$ P. Hooper

Department of Natural Sciences, Manchester Metropolitan University, Chester Street, Manchester M1 5GD, UK

e-mail: F.Raje@mmu.ac.uk

D. Radulescu $\cdot$ N. Burtea

National Research and Development Institute for Gas Turbines COMOTI, 220D Iuliu Maniu

Blvd., District 6, OP76, CP174, 061126 Bucharest, Romania

L. Leylekian et al. (eds.), Aviation Noise Impact Management, https://doi.org/10.1007/978-3-030-91194-2_6 
of local residents to noise. By providing a simple framework, focusing on the core aspects of noise management, airports would therefore be able to have the flexibility to adopt their own approaches as appropriate to their own situation. This also recognises that Member States may already have their own noise regulations and policies in place.

The Balanced Approach provides a flexible way to identify and transparently address specific noise problems. It comprises four principal elements:

1. Reduction of noise at source-by encouraging the development and use of quieter aircraft.

2. Land-use planning and management - to prevent noise sensitive developments close to airports and flight paths, and to mitigate noise impacts (i.e. through sound insulation).

3. Noise abatement via alternative operational procedures that separate aircraft from noise sensitive areas or reduce sound generated by aircraft by following low noise procedures such as reduced use of thrust.

4. Operating restrictions on aircraft at sensitive times (e.g. at night) or in terms of absolute numbers of movements.

As well as these guiding principles, an accompanying document 'Guidance on the Balanced Approach to Aircraft Noise Management' was produced to support airports in implementing interventions within these core elements. It is important to note that this guidance states that operating restrictions should only be applied as a last resort, after the other elements have been considered and applied, where appropriate. This acknowledges the key role played by aviation in the global socio-economic system, and that reductions in noise can be achieved at a lower economic cost when a stronger focus is placed on the other Balanced Approach elements.

The ICAO Balanced Approach was adopted into European Law through EU Directive 2002/30/EC, which was later replaced by Regulation (EU) No 598/2014. In the EU, legislation is set centrally, while implementation into local law occurs at the Member State level. This ensures that the exact implementation of the four Balanced Approach elements is at the behest of the contracting states, which can also choose to delegate their powers to a competent authority. Below this level, airports are generally encouraged to implement their own specific interventions designed to reduce impact, although this is commonly carried out in collaboration with external stakeholders, particularly National Air Navigation Service Providers and Civil Aviation Authorities. This approach ensures that aircraft noise problems at individual airports can be managed in both an environmentally and economically responsible way-achieving maximum environmental benefit in a cost-effective manner.

A snapshot review of Balanced Approach implementation across EU Member States undertaken at the start of the ANIMA project revealed considerable inconsistency in the implementation of the provisions of Regulation (EU) No598/2014. It concluded with the following core messages which were corroborated at a mixed stakeholder meeting (the Impact and Balanced Approach Expert Community supporting ANIMA—see Heyes et al. [13]): 
- The ICAO Balanced Approach is a good basis for action to reduce noise exposure, but guidance is required on the appropriate use and efficacy of different elements.

- Given that it is never possible to reduce noise exposure to zero, it is necessary to engage with affected communities, and to consider this issue in the context of the costs and benefits that accrue to them from living near to the airport, and of aviation in general.

- It is important that such engagement is a two-way process: of dissemination from the airport to communities and listening by the airport to community concerns, insight and priorities.

- All airports, of any size, need to consider aircraft noise and anticipate the consequences of growth. The 50,000-movement/ year figure for the application of the Environmental Noise Directive (END) is too simplistic and needs to be reconsidered. One solution could be to have a pre-qualification criterion that requires airports to begin the process of building noise management capacity and engagement with stakeholders, particularly on the issue of land-use planning.

- Management of noise impacts needs to be informed by quality data. Existing reliance upon noise modelling outputs or complaints analysis to inform Balanced Approach implementation can lead to sub-optimal outcomes. Appropriate engagement and dialogue between airports and their surrounding communities is an important prerequisite to assessing the nature and extent of noise problems and appropriate responses. Further policy and good practice guidance is considered to be helpful to facilitate this.

- It is clear that the industry is committed to reducing noise impact, but doing so requires collaboration across the board, between aviation stakeholders, and between different airports.

Specifically, in respect of Land Use Planning (LUP), the review highlighted the use of a range of anticipatory and mitigation tools. It also underlined that -in the desire to tailor to local conditions and only apply controls where necessary to avoid/minimise noise impact - there is considerable inconsistency in the utilisation of LUP provisions between Member States and airports therein [14]. A key explanation for the range of LUP outcomes is that at the heart of the decision-making process is the need to reconcile many, at times competing, demands; such as those of conservation, agricultural, highways and railways, recreation, municipal utilities, commercial, industrial, residential and institutional developments. The challenge for responsible authorities is to ensure a balance of uses that optimises social, environmental and economic benefits.

Land Use Planning, or land use management controls for an airport, attempts to achieve optimal utilisation of land through the use of zoning linked to noise exposure. This can be an effective method for limiting the increase in the number of residents located near airports, people who could become affected by aircraft noise in the future. Unfortunately, there has been very limited systematic evaluation of the use of land use planning tools to minimise noise impact over the last decade since the initiation of the ambitious ICAO/CAEP 5 work programme on Airport Planning and Land Use Planning. During this period, however, many airports have suffered from 
encroachment by noise-sensitive developments and, thus, the constraints to infrastructure growth have increased significantly. There remains a need for the assessment of land-use planning for noise impact prevention and mitigation if tools are to be developed that can help policy makers and communities (ICAO resolution A37-18).

The key challenge in attempting such assessments is recognition of the range of planning interventions available and how best to tailor their selection and implementation to particular airport contexts. The range of instruments available includes those which are anticipatory (such as noise zoning, transfer of development rights and comprehensive planning), those which are reactive (such as noise insulation programmes, real estate disclosure and building codes) and those which are financial (such as tax incentives, capital investment planning and noise-related airport charges).

The implications from other ANIMA deliverables (e.g. D2.4 [12] and D2.5 [16]), and in keeping with the priorities for communication and engagement, are that such tailoring is best achieved through consultation with local decision makers, urban planners, local communities, and other parties affected by noise impact. This should allow for the most effective utilisation of the land use planning tools available in the design of prevention and mitigation solutions.

This stakeholder consultation and engagement needs to explore the use of land use planning instruments both individually and in combination to assess their potential to address challenges such as:

- Changes to population distribution around airports (density and location).

- Provision of effective protection against night noise.

- How best to optimise the consequences of operational changes (e.g. optimising synergies between operational changes and land use instruments).

- How best to define and track the effectiveness of land use planning.

The development of guidance material and the adoption of proactive approaches to the use of LUP powers have led to some examples of good practice, for example, at Kiev and Catania airports (see [15]). Both have shown how national legislation helps the land use planning process and ensures that zones surrounding the airports are subjected to as little as possible uncontrolled or business driven development. Both airports recognise the key role of collaboration and communication between airport and relevant local authorities. This approach enables the needs of each party to be shared and understood, and the long-term implications arising from the potential development of noise sensitive buildings close to airports considered and controlled by regional decision makers. Thus, the long-term health and economic future of the region can be safeguarded - the airport is better able to grow, whilst the health impacts of living near to an airport can be mitigated.

Another example of good practice comes from Australia. A recent report by TO70 ([37], p. 25) for the City of Canning examined the case for a new runway at Perth Airport. It highlighted the importance of the land use planning near airports, stating that 
...land use planning is the process in which noise sensitive areas, such as residences, hospitals and schools are not placed on or near the area surrounding airports. Land use planning is usually conducted by local and state councils and should follow state planning policies to avoid development in high noise areas surrounding airports. Australian standards (AS20212015) and NASF, Guideline A provide guidelines for appropriate areas for building and development.

Many land use management strategies utilise passive sound mitigation measures, which consist of the use of noise-isolating materials and various forms of noise insulation. Homes and noise sensitive buildings situated near airports are usually insulated with assistance from the government or airports themselves via noise insulation schemes. Active noise management involves reducing noise through operational procedures or reducing noise from the source.

State and local government are required to use ANEF contours as guidance during land use planning. Australian Standards AS2021-2015 use ANEF contours to guide land use planning for local councils.

To70 ([37], p. 26) continued by setting out the requirement for noise contours to be produced every five years at Perth Airport to assist land use planning around the airport. The report states further that

It is important to point out that this example of good practice also comes with a caveat: while integrated land use planning is desirable, the frequency and intensity of noise need to be considered too, "as these factors play a major role in annoyance" (p. 26). In addition, there is a need to recognise "that ANEFs are based on a forecast of aircraft movement and therefore actual noise experienced will vary" (p.16).

Other examples of good practice can be found: Box 1.

\section{Box 1 Existing best practices on land use planning (a)}

Effective Land Use Management to avoid the encroachment of incompatible developments near airports tends to be found where a more integrated approach is taken to the development of planning strategies and systems of planning control use appropriate methods/tools to understand the extent of the spatial impact of airport activities. This often takes the form of a wider vision of the airport and the city/region that minimises future constraints on air traffic development.

In Australia and the US, LUP is considered an environmental protection action policy tool which is integrated into the overall planning system. However, the responsibility and capacity for planning and implementation is different in the selected case-studies illustrated below.

\section{The Australian Experience}

The approach to land-use planning around airports became an important public policy issue following the privatisation of airports in 1990 [11].

State plans and strategies cover four relevant approaches: land use planning directives, regional planning aspirations and structures, aviation-related statements, and some airport-specific instruments. 
Regional strategies provide a higher degree of spatial resolution. In metropolitan areas, the airports are considered 'specialised activity centres' in recognition of their function as gateways for economic growth. For example, the Metropolitan Strategy for Sydney specifies Sydney Airport and its environs as a specialised centre generating 'metropolitan-wide benefits' with over 36,000 jobs (about a third at the airport itself). This shows a clear approach to a wider planning system which includes the airport and its requirements in the municipality strategic development.

The Aviation-related and airport-specific directives are more targeted and connect to ensuring adequate noise and safety buffers around airports. Central to these provisions is the use of Australian Noise Exposure Forecasts based on summing the energy from individual aircraft effective perceived noise levels. These are required from airports every 5 years and must forecast the consequences of airport development and associated air traffic changes to a minimum of 20 years. These contours can then inform appropriate zoning of development types around the airport on the basis of future changes rather than existing noise foot printing, thereby in theory future-proofing the airport against the encroachment of incompatible land uses [36]. Protecting the environment of nearby communities through noise mitigation is included in this provision, as should residential areas be predicted to fall into unacceptable levels of exposure in future years (i.e. $>20 \mathrm{ANEF}$ ), there is a mandate for the provision of sound insulation.

The recognition of airports as 'special use' land use zones, is designed to ensure, through the ANEF, the imposition of noise protection buffers. Of course, there are challenges with the production of ANEF as they are only as accurate as the forecasts for infrastructure and fleet changes, but nevertheless the forecasting out to a minimum of 20 years is intended to provide an effective protection against encroachment.

\section{The US Approach}

The US efforts present a vivid picture of the importance of land use compatibility planning, linking the development approach to methods and tools that illustrate and assess the air traffic growth. There are some good examples of integrated planning approaches at State level, but not yet at the Federal level. The Airport Cooperative Research Program (ACRP) includes a land use survey and case studies that explore issues relating to LUP around airports. The planning system has an integrated approach, a two-way planning system that links land use planning vertically and horizontally to other planning processes. The planning system also has an iterative character that allows continual adaptation and avoids the one-time establishment of a plan that could soon become outdated. The plan is created jointly by all institutions involved in the development of an airport and the city or region it serves, and it is implemented 
separately by sectors, being coordinated by a lead agency. Coordination of all stakeholders' requirements is well managed throughout the process.

While it dates back a few decades, the example of land-use management around Washington Dulles International Airport illustrates some of the US best practices in tackling the challenging aspect of LUP (Dulles Int'1, n.d.). This airport opened for service in November 1962, but, from the initial planning and development phase, aircraft noise, and its impact on regional communities, was a primary consideration. Thus, the airfield design limits close-in residential development by integrating: " $11,000+$ acres within the airport perimeter, centrally-positioned runways, and a large area ( 8,000 feet) buffers from runway endpoints to the estate perimeter". This illustrates that the predicted development of the airport was considered from the start. In addition to the planning process, the FAA (the initial airport operator until 1987) and the Airports Authority have worked closely with the two neighbouring Counties (Fairfax and Loudoun) to deliver residents compatible land-use protection through an efficient county planning and zoning strategy. Consequently, in 1993, Loudoun County was identified as a national frontrunner in land-use planning associated with a growing international airport.

\section{Box 1 Existing best practices on land use planning (b)}

\section{The Singapore Story}

This case study is another illustrative example of the integrated approach of an airport and a city, in which a harmonised planning system serves both the citizens and the airport.

The comprehensive planning that went into the development of Changi Airport, and the integrated manner in which it was carried out is considered best practice by many. Singapore's approach involved unique urban-planning constraints and trade-offs brought about by both civilian and military airports, and took account of ways to exploit airport developments to catalyse urban and economic development. Further information about the land use planning around Changi Airport can be found at.

https://www.clc.gov.sg/docs/default-source/urban-systems-studies/uss-int egrating-the-planning-of-airports-and-the-city.pdf

Despite evidence of good practice at specific airports, the broader challenge is for the sector as a whole to harness the full range of planning powers to ideally prevent noise problems in an optimal manner. And, where this has not been possible, airports would mitigate impacts by the use of the likes of insulation and buy-out schemes or when other options have been exhausted, compensation programmes. A 
key achievement of effective land use planning would be the avoidance of further residential developments in areas that would endanger the reduction in noise impact previously achieved and the conversion of existing incompatible land-uses to ones more in keeping with the prevailing noise environment. Achieving this end is by no means straightforward and takes concerted action involving a range of stakeholders if planning priorities are to be harmonised and airport development protected from future constraint. Our case from Iasi Airport in Romania demonstrates why it is essential to start the process of stakeholder engagement at an early stage in airport development if encroachment of incompatible land uses is to be avoided.

\section{Iasi Airport Case Study}

\section{Introduction}

Iasi International Airport, known officially as "Aeroportul Internațional Iași, România" (ICAO: LRIA, IATA: IAS), is located in the North-Eastern part of Romania. Situated at a distance of $3.48 \mathrm{~km}$ East from the Iasi city, the airport has an elevation of $411 \mathrm{FT}$, with a reference temperature of $30^{\circ} \mathrm{C}$ [5] (see Fig. 1). The airport offers three domestic routes (Bucharest, Cluj-Napoca and Timisoara) and multiple international flights to 15 countries (Israel, France, Great Britain, Italy, Spain, Belgium, Germany, Cyprus, Netherlands, Denmark, Austria—regular; Egypt, Tunisia, Turkey, Greeceseasonal). Eight airlines operate at Iasi Airport (TAROM, BLUE AIR, WIZZ AIR, AUSTRIAN AIRLINES, AMC AIRLINES, AIR BUCHAREST, AEGEAN and

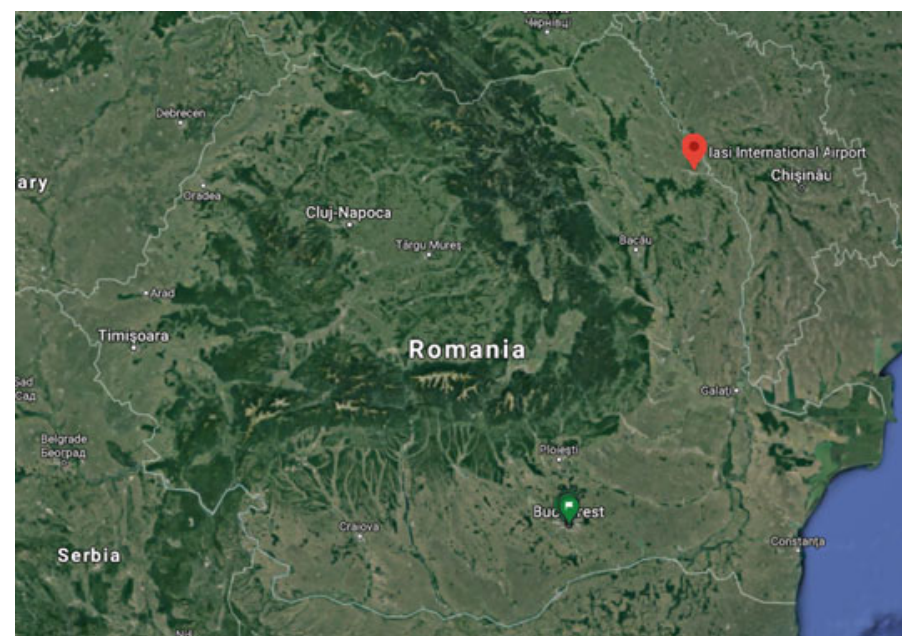

Fig. 1 Location of Iasi Airport, Romania. Google Maps, Iasi International [18] 
ONUR) [1]. In terms of infrastructure, the airport has 1 heliport, 3 terminals and one runway (RWY 14/32) of $2400 \mathrm{~m}$ [2].

Iasi Airport is the regional airport for the North-East of Romania, serving a population of around 4 million and a catchment area of approximately $37000 \mathrm{~km}^{2}$ that includes the County of Iasi, along with the neighbouring counties (Bacau, Botosani, Neamt, Suceava and Vaslui) and the Republic of Moldova (see Fig. 2).

In terms of connectivity, the airport is linked to both road and railway infrastructures, facilitating access from nearby communities, as well as from different cities across Romania.

Before COVID-19, Iasi Airport was considered to be a fast-growing airport, and this can easily be seen in the increasing number of aircraft movements from Fig. 3. Even so, Iasi Airport has remained throughout the years among the top five Romanian airports with the highest air traffic density [19-24].

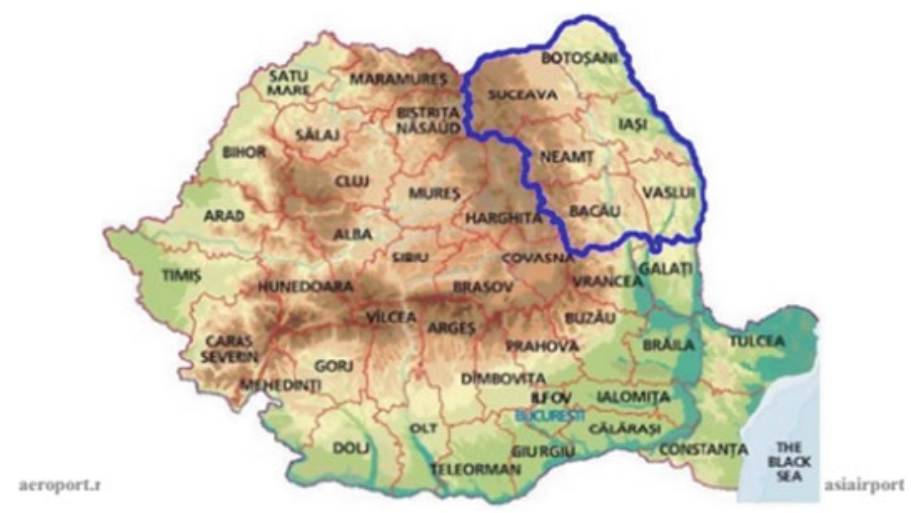

Fig. 2 Catchment Area, Iasi Airport. AEROPORTUL IASI—Date demografice, [3]

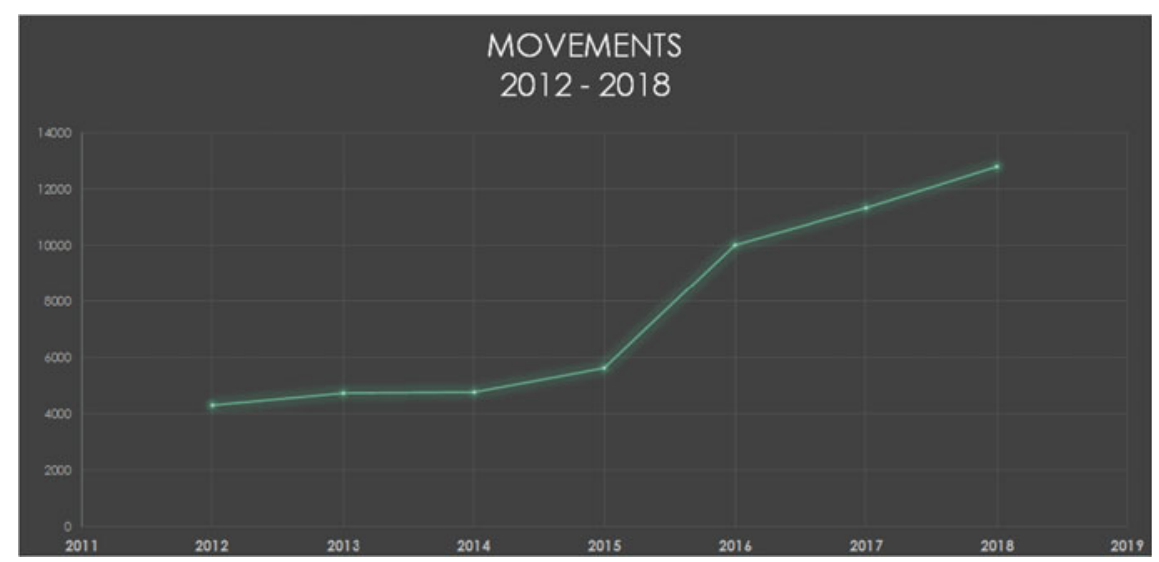

Fig. 3 Evolution of aircraft movements on Iasi Airport (2012-2018). Iasi Airport [18] 
In the immediate vicinity of the airport there is an important actor from the Romanian aerospace industry sector (aircraft maintenance), "Aerostar SA-MRO Iasi". In addition, other strategic facilities can be found very near to the airport, such as the military base "Batalionul 151 Infanterie" and the aerodrome for general aviation "Aeroclubul "Alexandru Matei” Iasi”.

\section{Experience with Aircraft Noise Management Prior to ANIMA}

In 2005, the Environmental Noise Directive (2002/49/EC) was adopted into National legislation through the Governmental Decision "H.G. nr. 321/2005" [34]. Its alignment to the Environmental Noise Directive was further addressed through various updated versions of H.G. no. 321/2005, through: H.G. no. 674/2007 [33], H.G. no. 1.260/2012 [32] and H.G. no. 944/2016 [31]. According to these provisions, Iasi Airport (classified as an 'urban airport') had to prepare Strategic Noise Maps and Action Plans, in 2012-2013 and 2017-2018, although the number of aircraft movements was below 50,000 movements/ year threshold for their mandated production. Based on the findings from the first and second round of Strategic Noise Maps, the airport management concluded that encroachment was the most important concern, especially in the case of a fast-growing airport. The flight paths and the process of encroachment over time (700 m distance from the runway threshold to the closest fence surrounding a residential building-2020) is shown in Figs. 4 and 5. Therefore, the airport's long-term strategy was defined such that maximum effort would be made in support of legislative changes for land-use planning implementation in conflict areas, while, at the same time, focus would also be on raising awareness about the need to consider residential developments and airport operations in a coordinated manner in order to reduce the number of people exposed to aircraft noise. However, land-use planning with the aim of managing aircraft noise was absent within the National legislative framework.

\section{Annoyance Case Study (2015)}

Within a joint initiative (Romanian Social Survey on Noise Annoyance), Iasi Airport was involved in an annoyance study, in partnership with INCDT-COMOTI, the Faculty of Psychology (University of Bucharest, Romania) and SINTEF (Norway). The initial research driver was to understand and investigate the real situation behind noise complaints. The study used a survey based on the psychometric characteristics of WHOQOL ("The World Health Organisation Quality of Life") [39] and on the standard questions for noise annoyance from ISO 15666 (ISO/TS 15,666:2003, 2003). The outcomes from this study highlighted the need for collaboration between stakeholders to reach a common understanding of the context and the issues in aircraft noise management. In addition, the absence of funding opportunities, the lack of expertise and trained experts in Romania on aircraft noise and annoyance, together 


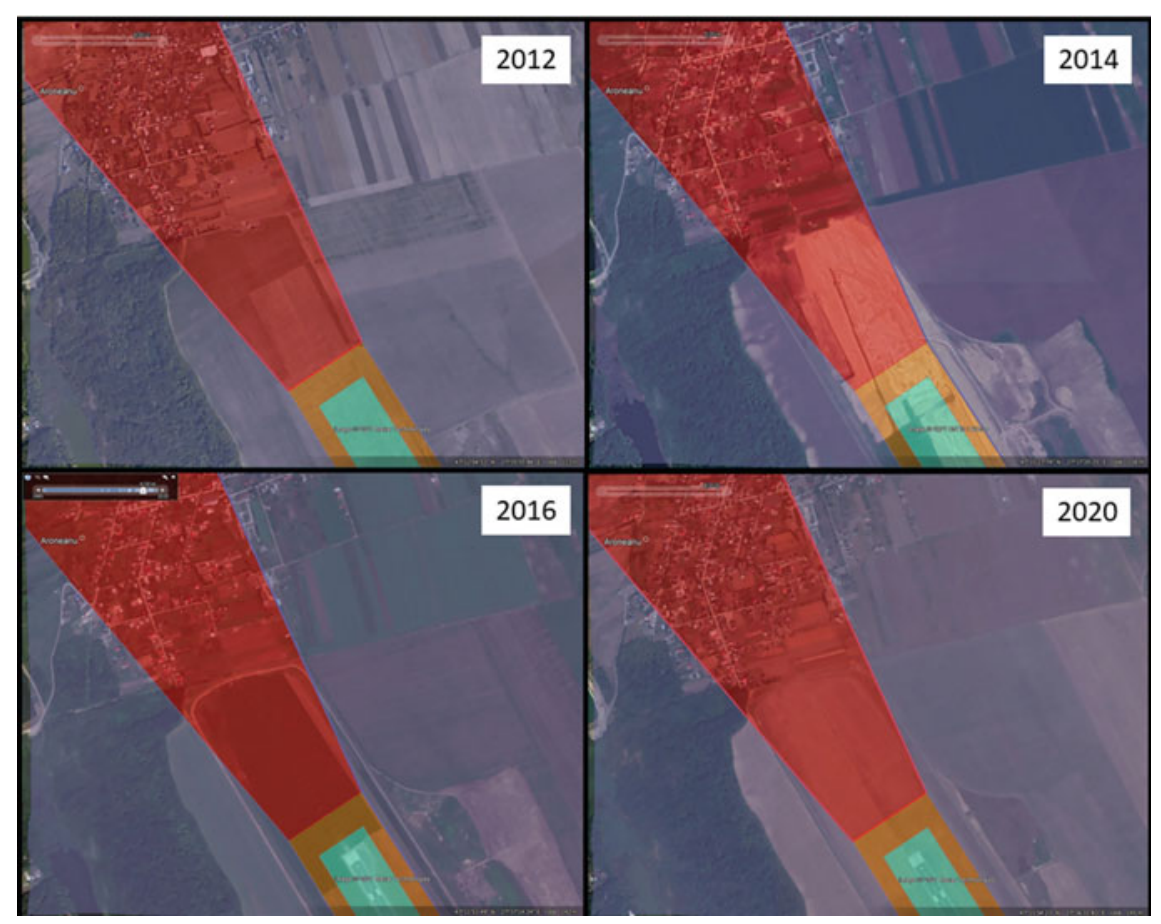

Fig. 4 Flight paths over Aroneanu Village at the end of RWY14. Iasi Airport [18]

with the lack of available research at a National level were identified as the main barriers to further addressing annoyance.

\section{Progress Within the ANIMA Project}

\section{Legislative Framework in Romania}

At the beginning of the ANIMA Project (October 2017), Iasi Airport started to be proactively engaged within the task "Pan-European Review of Existing Regulations and Mitigation Strategies" [14], in direct collaboration with INCDT-COMOTI and researchers from Manchester Metropolitan University. At this time, the transposition of the Environmental Noise Directive (H.G. 321/2005) was the most important legislation related to managing aircraft noise and was initiated by the Ministry of 


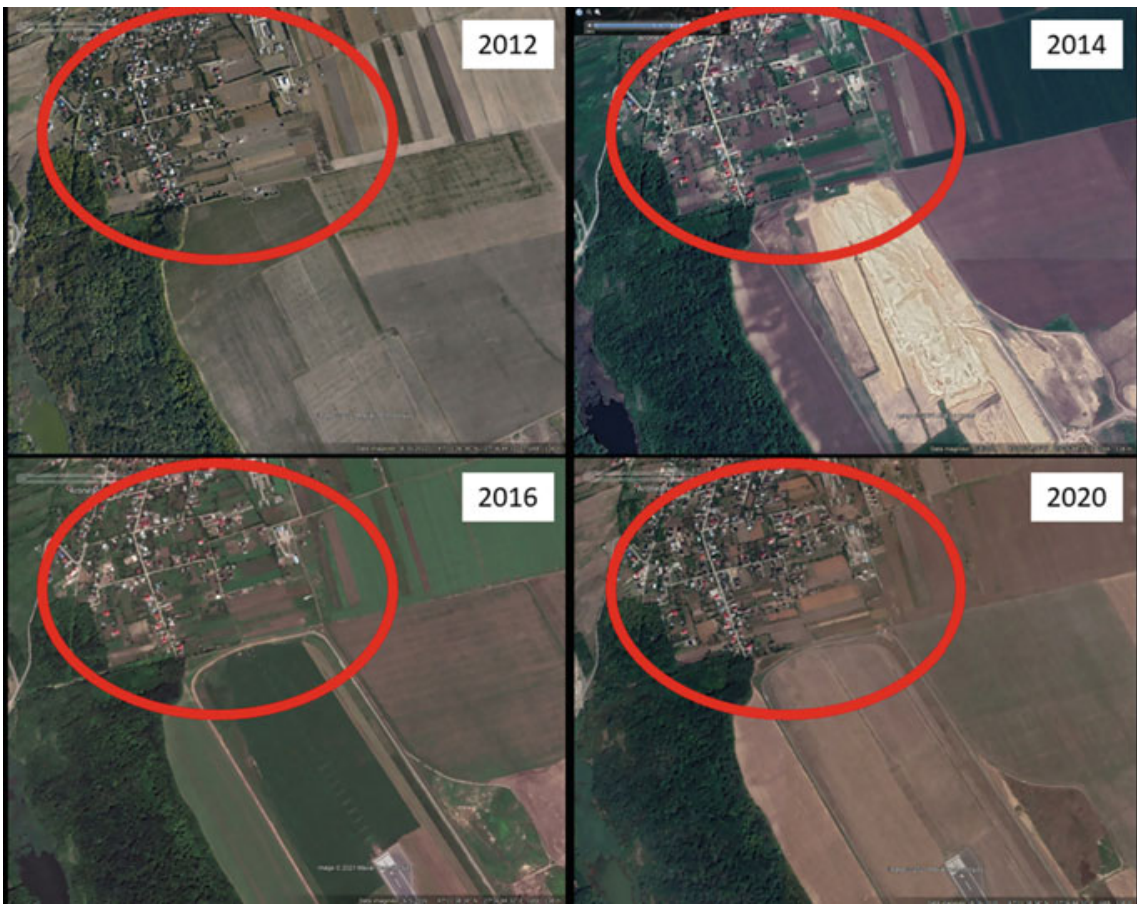

Fig. 5 Residential buildings Aroneanu Village at the end of RWY14. Iasi Airport, [18]

Environment. A second legislative instrument was also available, related to the transposition of the 2002/30/EC Directive ${ }^{1}$ regarding operating restrictions, which had been initiated by the Civil Aviation Authority. The concept of land-use planning was still only theoretical, despite being a widely discussed topic. The findings from this ANIMA task revealed that land-use planning was not entirely absent from the national legislative framework, but spread between different legislation and with no specific provisions for reducing exposure to aircraft noise.

\section{Visit to Heathrow (May 2018)_Learning from an Experienced Airport}

In order to foster a better understanding of practices related to land-use planning, a meeting was organised between a noise expert from Heathrow Airport and a representative from Iasi Airport in 2018. The aim of this initiative was to facilitate the transfer of 'best practice' and 'lessons learnt' knowledge from an airport with a longer history of experience in managing aircraft noise through land-use planning, towards

\footnotetext{
${ }^{1}$ Repealed by Regulation (EU) No 598/2014 of the European Parliament and of the Council of 16 April 2014 on the establishment of rules and procedures with regard to the introduction of noiserelated operating restrictions at Union airports within a Balanced Approach and repealing Directive 2002/30/EC.
} 
an airport that was at the beginning of this journey. One key conclusion was the fact that various measures applied successfully by some airports may not be feasible or reach the same level of effectiveness, at other airports, due to differences in context (e.g. being a private airport or state-owned), available legislative frameworks and available resources (e.g. funding opportunities, experts and expertise in the region).

\section{Iasi Workshop (July 2018)—Raising Awareness About the LUP Issue (Common to All Airports)}

In the same year, an ANIMA workshop was organised in Iasi to raise awareness about the importance of addressing land-use planning with the aim of reducing the number of people exposed to noise, in the context of fast-growing airports and increased encroachment issues.

Various stakeholders (representatives from communities living in the proximity of Iasi Airport, from the Ministry of Environment and the Civil Aviation Authority, an airline, representatives from five Romanian airports - under the scope of the 'Romanian Airports Association', independent experts and ANIMA partners) were involved in these discussions. They presented their views with respect to managing aviation noise in Romania and described challenges that could appear in the absence of effective land-use planning practices. In spite of competing agendas, it was commonly concluded that land-use planning for reducing the number of people exposed to noise had become an urgent matter and joint efforts were needed to address this. Supplementary to this workshop, Iasi Airport and its local ANIMA partner (INCDTCOMOTI) initiated discussions with representatives from the Ministry of Transportation, the Ministry of Health, local and regional authorities, different airlines, the Romanian Air Navigation Service Provider (ANSP)_ROMATSA and research experts (including ANIMA partners), to increase the efforts in raising awareness about the existing challenges and the importance of collaboration to ensure effectiveness. At this point, the most important issue was finding the balance between reducing the number of people exposed to aviation noise, preventing further encroachment and ensuring the capacity of aircraft operations in the future, in line with air traffic forecasts.

All these efforts were furthered within the ANIMA Project during the subtask "Balanced Approach to Noise Management" [15] and the task "Airport Exemplification Case Studies" to be reported in ANIMA deliverable D2.11.

An initial result (2018) from these discussions was the introduction of the requirement to implement Noise Abatement Departure Procedures (NADPs), which was included within the Romanian Aeronautical Information Publication in 2021. For some airports, this requirement became mandatory, while for other airports (Iasi Airport included), it is in the form of a recommendation.

Another important legislative change in 2019 (Noise Law), ${ }^{2}$ related to the transposition of the Environmental Noise Directive. The new proposal was initiated and

${ }^{2}$ LEGE nr. 121 din 3 iulie 2019 privind evaluarea și gestionarea zgomotului ambiant. 
disseminated for discussion by the Ministry of Environment and took into account many issues raised at the workshop in Iasi, mostly related to the clarification of which authorities are responsible for managing noise produced by air traffic, while reinforcing the importance of collaboration between many stakeholders. This legislative change empowered the application of END provisions, changing the status of the legislation from a Governmental Decision to a Law. Through this change, various other stakeholders (the Air Navigation Service Provider, the Civil Aviation Authority, and the Ministry of Health) became responsible for airport noise management in an official capacity, which is a notable difference from the previous situation where the airport was the sole responsible entity (apart from Governmental bodies), but without any decision-making power in most cases (especially on LUP).

Additional legislative changes $[27,30]$ took place, related to the application of provisions from the Regulation (EU) no. 598/2014, which further enforced the need to have a collaborative approach for the implementation of noise operating restrictions, as well as the need to address land-use planning before considering operating restrictions as a solution. One important change is that the Civil Aviation Authority has to support the environmental protection authority with assistance in the evaluation of aircraft noise impacts at airports (balancing safety and environmental protection requirements) and the ANSP has to provide the information that helps in the process of evaluating compliance with noise operating restrictions.

An updated version of the "Air Code" [28] was also proposed for adoption (2019) and publicly disseminated for feedback. Among its provisions, it requires that Strategic Noise Maps have to be taken into consideration by the airports within their Airport Development Plans, as well as by local and regional authorities for land-use planning within the Urban Development Plans. The same authorities have to implement noise zoning strategies around airports, yet a specific timeframe for implementation and a clear methodology for noise zoning are still missing (methodology expected to be published by the Ministry of Environment). It is also important to note, in this context, that the Ministry for Regional Development and Tourism is currently the only stakeholder responsible for the approval of construction in the vicinity of airports. In addition, avoiding residential developments around powerful sources of noise (airports included) is only at the level of recommendation, with only few provisions and details for practice suggested [35]. Another important provision is that noise exposure has to be one of the criteria used in the design of new operating procedures or modification of existing ones.

\section{Conclusions}

Although many steps have been taken towards the implementation of land-use planning provisions, it was initially identified that it would first be necessary to ensure that the existing legislative framework on managing noise from air traffic was complete and harmonised between the environmental protection provisions and the aviation provisions, thus avoiding inconsistencies and barriers in implementation. In spite of 
the fact that all these efforts were in support of the implementation of ICAO Balanced Approach, especially land-use planning, this initiative is still at an early stage and needs further legislative harmonisation with the urban development legislation, in order to ensure its effectiveness in implementation. However, changes in legislative frameworks require a long period of time and, thus, increase the risk of missing opportunities to use land-use planning as a preventive measure. Therefore land-use measures would be limited to using planning tools to mitigate existing impacts (e.g. buy-out/relocation of residents, demolition of buildings from conflict areas, noise insulation schemes, and closing the airport), which is considered to imply higher costs and require more effort and time to obtain effective solutions. These challenges emphasise the necessity for having a common European strategy on land-use planning (potentially complemented by a common noise metric and approaches to planning more generally), together with available funding opportunities to support implementation at national and local levels.

In the case of small but fast-growing Iasi Airport, there is no budget or other necessary resources allocated for managing airport noise. The absence of a Governmental funding scheme for reactive noise impact measures, dramatically limits the options of any Romanian airport to act upon this issue. The remaining solution is to cooperate with the National legislative bodies, to develop an appropriate framework to prevent further encroachment.

As the overall air traffic evolution and forecast scenarios show a constant increase in aircraft operations, land-use planning and management was considered by Iasi Airport as the best option to ensure the necessary means to maintain or reduce the number of people exposed to aviation noise. From the position of a state-owned airport, Iasi Airport, as well as most Romanian airports, has little decision-making power in land-use and, therefore, communication and engagement with the relevant stakeholders and affected communities has been of utmost importance in opening up the dialogue about developing land-use planning provisions within the National legislative framework.

\section{Insulation Case Study}

\section{Introduction}

As suggested previously, where anticipatory planning powers do not prevent encroachment, there is a role for mitigation. One example of this approach is the adoption of sound insulation schemes by airports. The cases of insulation at Heathrow and Marseille Airports are examined here to explore this type of reactive intervention. 


\section{Background}

ANIMA undertook to examine, through qualitative research, whether interventions implemented by airports or other stakeholders in airport regions could have an impact on residents' quality of life [26]. In this study, sound insulation was studied at Marseille and Heathrow Airports. Concerns about aircraft noise impact date back to the 1950s and 1960s when jet engines started to be introduced, and international aviation became more popular [38]. Thus, a key aim of the insulation schemes was to reduce noise complaints and general community dissatisfaction by reducing noise disturbance attributable to aircraft overflights.

\section{Sound Insulation Schemes Studied}

\section{Marseille}

In 1997, the French state implemented a specific sound-proofing assistance system for large airports. This meant that residents affected by aircraft noise could then receive a grant for sound insulation for their homes. The system was originally managed by the National Environment and Energy Management Agency and financed by a general tax on polluting activities. Now, the grant is exclusively financed by airlines via a tax on aircraft noise pollution (TNSA), levied by the DGAC (Directorate General of Civil Aviation) according to the "polluter pays" principle. The criteria for eligibility around Marseille Airport are that the accommodation is located inside the annoyance map contours ${ }^{3}$ and was built before the noise annoyance plan had been created.

In order to explore quality of life and, in particular, the concept of scheme fairness, focus groups were carried out in three areas around Marseille Airport- two in the annoyance noise map and one outside the annoyance noise map contours, following these criteria:

- Eligible to the grant/insulated: City of L'Estaque (Marseille airport).

- Eligible to the grant / non-insulated yet: city of Marignane (Marseille airport).

- Non-eligible / non-insulated: City of Vitrolles (Marseille airport).

The assumption was that people who were situated in the grant area and had already been in receipt of insulation would be more likely to appreciate the intervention than the other participants. Moreover, it was important for us to investigate the perception of those people who could be insulated but had ignored the process of the insulation program. Indeed, it was hypothesised that the insulation scheme is not well known by people, even those who are eligible for it. This could also have an impact on their perception, because it deals with issues of fairness. Finally, the intention was to investigate this kind of intervention in an area with a mild climate,

\footnotetext{
${ }^{3}$ At Marseille, an annoyance map reflects a small section of a larger noise map (called an exposure noise map) which includes most noise affected areas.
} 


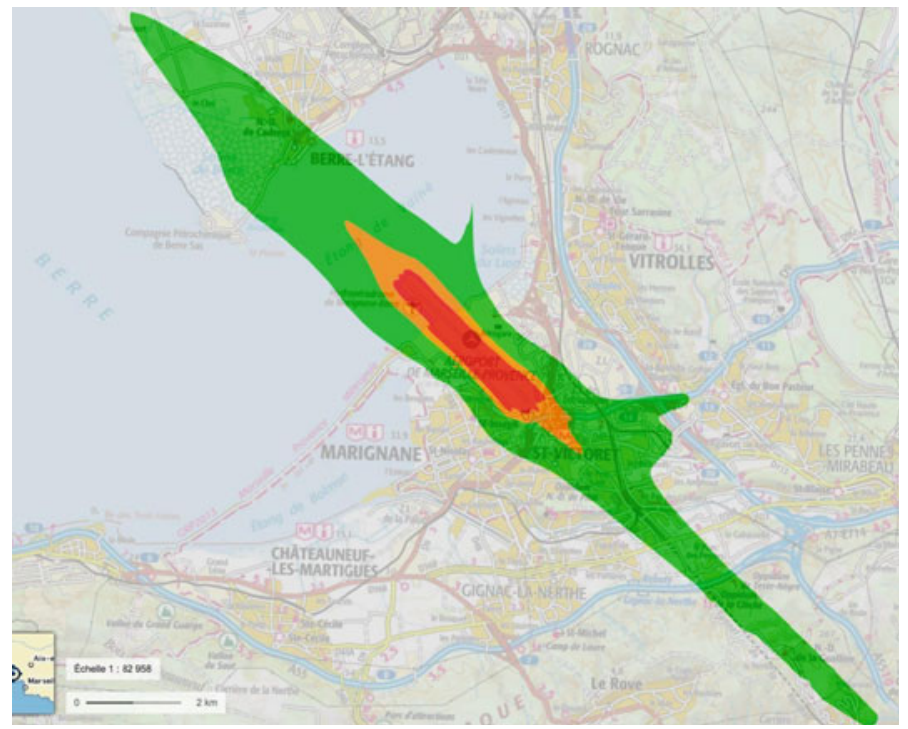

Fig. 6 Annoyance noise map contours valuable for insulation scheme in Marseille. Green areas: $55 \mathrm{~dB}<$ Lden $<65 \mathrm{~dB}$; orange areas: $65 \mathrm{~dB}<$ Lden $<70 \mathrm{~dB}$; red areas:Lden $>70 \mathrm{~dB}$. Kuhlmann et al Source [26]

because it was assumed that it would not be as well perceived in comparison to colder areas. It was anticipated that the results could help to better frame the intervention according to the location, that is, that there should be knowledge about the location and potentially a decentralisation of the decision-making bodies.

The annoyance map in Fig. 6 illustrates the range of noise affected areas by different colours.

Another focus group was also conducted in order to consult the people involved in a noise pressure group.

\section{Heathrow}

Sound insulation as an intervention to help mitigate aircraft noise impacts around Heathrow began being discussed in the, resulting in a range of schemes being developed over the ensuing 60 years. In the mid-1990s, a voluntary daytime noise insulation scheme was introduced by Heathrow Airport, followed by a voluntary night noise insulation scheme early in the following decade. By 2014, Heathrow had started to offer the Quieter Homes Scheme (QHS) for those residents living closest to the airport within the $69 \mathrm{~dB}$ LAeq, $16 \mathrm{~h}$ aircraft noise contour. An overview of these schemes is provided: Box 2 . 


\section{Box 2 Brief details of sound insulation schemes at Heathrow Airport}

The (Residential) Day Noise Insulation Scheme (or Day Scheme) is based on the $199469 \mathrm{~dB}$ LAeq, $18 \mathrm{~h}$ contour and is designed to protect those homes exposed to the aircraft noise in the day, including in the early morning arrival period before $06: 00$. These properties are eligible to receive $50 \%$ of the cost of replacement windows and external doors, or free secondary-glazing, and free loft insulation and ventilation. 9300 homes fall into this scheme's boundary.

The Night Noise Insulation Scheme (or Night Scheme) is designed to address the impact of night flights on local residents. The scheme boundary is based on the footprint of the noisiest aircraft regularly operating between 23:30 and 06:00. Eligible properties are entitled to receive 50\% of the cost of replacement bedroom or bed-sitting room windows, or free secondary glazing of bedroom or bed-sitting room windows, and free loft insulation and ventilation. Approximately 37,000 homes fall within this scheme's boundary.

The Quieter Homes Scheme (QHS) applies to homes based on the 2011 $69 \mathrm{~dB}$ LAeq, $16 \mathrm{~h}$ contour. It covers the full cost of carrying out the work which can include loft and ceiling insulation, double-glazing or external door replacements and loft and ceiling over-boarding. Around 1200 homes located close to the airport are entitled to this scheme (Fig. 7).

Unlike the insulation scheme funding model in France, Heathrow has introduced its range of noise control and mitigation measures voluntarily, since legal instruments

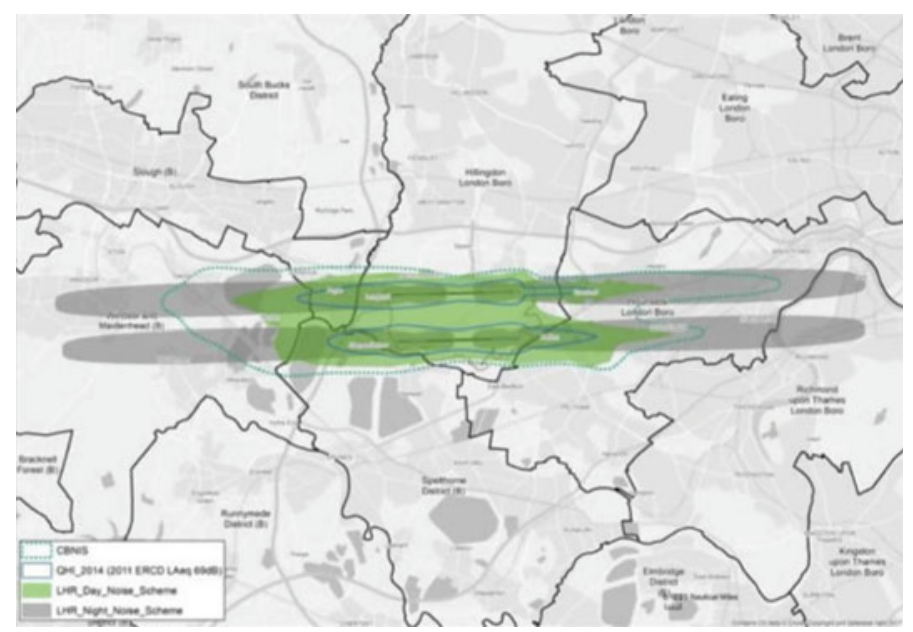

Fig. 7 Boundaries of heathrow noise mitigation schemes. Source Heathrow Noise Action Plan 2019-23 @ https://www.heathrow.com/content/dam/heathrow/web/common/documents/com pany/local-community/noise/making-heathrow-quiter/noise-action-plan/Noise_Action_Plan_2 019-2023_Supporting_Annexes.pdf 
related to sound insulation at Heathrow have expired. However, the prospect of statutory action is usually highlighted by the government if appropriate 'voluntary' actions are not undertaken at UK airports. For further information about the guidance around voluntary action, please see Box 3 .

\section{Box 3 UK Guidance on sound insulation}

In the UK, under Sect. 79 of the Civil Aviation Act (as subsequently amended) the government has powers to direct airport operators to implement noise insulation schemes. Although the prospect of statutory action is usually highlighted by government if appropriate 'voluntary' actions are not undertaken, Heathrow, Gatwick and Stansted as designated airports, along with many of the larger nondesignated airports in the country have introduced their own noise insulation schemes on a voluntary basis or in response to planning conditions/agreements; schemes operated at other UK airports tend to be derived from or closely resemble the designated airport schemes. Such has been the effectiveness of these initiatives that the Government chose not to amend Sect. 79 in light of conclusions to the consultation on the control of noise from aircraft published in 2003.

The UK government remains committed to the idea that aircraft noise problems are best resolved locally and that airport operators should be expected to take all practical steps to ensure that disturbance to those living in the surrounding area is kept to a minimum ([7]: 7). Indications as to what constitutes 'all practical steps' can be found in the Aerodromes (Noise Restrictions) (Rules and Procedures) Regulations 2003 that implemented ICAO's balanced approach outlined above, and more generally in the White Paper of the same year. The 'balanced approach' was adopted as EU policy in March of 2002 when the European Parliament and Council approved on the Directive 2002/30/EC on the establishment of rules and procedures with regard to the introduction of noise-related operating restrictions at Community airports.

The White Paper "The Future of Air Transport" [7], set out a strategy for the future of the industry in the UK that 'balances' the desire for growth with the need to 'reduce and mitigate the environmental impacts of air transport and of airport development' (p.29). It identified the measures that the government expects airport operators to adopt in order to help those affected by noise when new airport development takes place, these include:

- A continuation of the voluntary noise insulation grant schemes which take as their guideline threshold the 69dBA Leq $16 \mathrm{~h}$ contour for 2002.

- The adoption at larger airports (those with more than 50,000 movements a year), of mitigation measures that:

- Offer households who are subject to high levels of noise (69dBA Leq or more) assistance with the costs of relocating; and 
- Offer acoustic/sound insulation (applied to residential properties) to other noise sensitive buildings, such as schools and hospitals, exposed to medium to high levels of noise (63dBA Leq or more).

Thus, in the UK, the extent and generosity of sound insulation schemes is largely determined by voluntary action. The value of these actions in maintaining/improving relationships with local communities is emphasised in the UK Airport Operators Association's Environmental Guidance Manual for Airports.

In order to understand peoples' experience of living in the vicinity of/under enroute paths to/from Heathrow and their views on sound insulation, telephone interviews were carried out in September 2020. While focus groups had been planned for this aspect of the work also, interviews were adopted due to the need for social distancing during the pandemic. Participants were recruited through a local civic group, HACAN (Heathrow Association for the Control of Aircraft Noise) and included ten respondents. This group was purposively selected as their individual membership of HACAN, whose role is to be a voice for those under Heathrow flight paths, indicated that they would have some willingness to discuss issues related to aircraft noise. It should also be noted that there was a likelihood that some of the group may have had a willingness to oppose the airport and its activities too. This is something that the research team were aware of but it was agreed that the group's views would still provide insight into individual views amongst a small self-selected population. The interviews covered residents' satisfaction with their area and issues affecting their quality of life, their views about the airport and about the sound insulation offer, and an exploration of the value they placed on the intervention.

Since this was not a randomly selected group of interviewees but a group for whom noise was clearly already a factor, there needs to be a caveat about the representativeness of the results. Nevertheless, this was a motivated group of individuals who were willing to give their time to discuss quality of life in relation to aircraft noise-something that was of immense value to the researchers during continued restrictions due to the COVID-19 pandemic which prevented the initially planned questionnaire and focus group approach.

All ten interviewees were located to the East of the airport and variously affected by westerly arrivals (close in at Hounslow and further out along the arrival path) or easterly departures (one under the flightpath taking $40 \%$ of easterly departure traffic). All had been in their properties for long periods, except for one participant who had moved from an area near the airport to one which was even closer and had been surprised by the apparent increase in noise intrusion, feeling that the move had been a mistake (Fig. 8). 


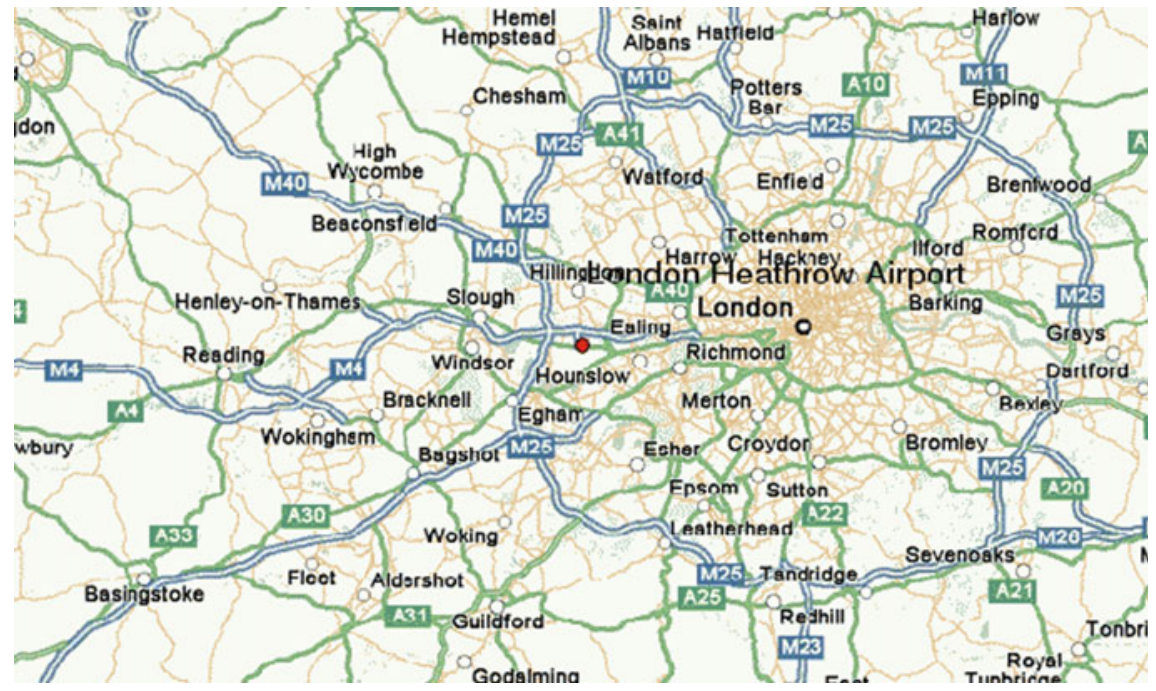

Fig. 8 Location of Heathrow Airport. Source Google Maps, 2020

\section{Sound Insulation at Marseille and Heathrow-Research Results}

The research undertaken at Marseille, involving four focus groups, suggested that insulation.

- was useful for lessening the effects of noise in wintertime when windows are closed.

- does not have any effect on air pollution caused by aircraft.

- seems to be very effective and can reduce stress and fear of crashes when people are inside their home.

- improves thermal comfort and contributes to a reduction of household energy bills.

The Marseille results revealed that a sound insulation intervention should take account of not only the indoor noise but also the outdoor noise exposure. In addition, they indicated that it is necessary for attention to be paid to the capacity of the intervention to improve social interactions in the respondents' residential area and, in particular, at home. The insulation scheme was seen as a good way to avoid annoyance from indoor noise exposure, but it had to be complemented by other interventions, especially when noise impacted areas are situated in a warm climate area (thus decreasing the time spent with closed windows). Despite these findings, the insulation scheme was well regarded by participants who intended to continue to avail themselves of the intervention.

With specific reference to ineligible participants at Marseille, there was varied knowledge of sound insulation. Nevertheless, participants had a favourable attitude to the insulation scheme procedure itself, even though it was considered unnecessary 
and ineffective for noise outdoors and during the summer period when windows remain open all day. However, they criticised the delineation of the outline of the noise annoyance map. In addition, they suggested that the annoyance map be scalable to reflect the increase in traffic and be reviewed more regularly. This group expressed concern that enough attention was not drawn to the intervention and that its availability and details had not been sufficiently communicated to the general public and potentially eligible people.

At Heathrow, drawing on the qualitative interviews, the research suggested that there was generally a low level of awareness of what the airport does to minimise noise exposure. Unsurprisingly, then, there was a low level of awareness of insulation provision. Participants drawn from the airport amenity group generally agreed with the principle of addressing the experience of the most noise affected, although the means for determining this was criticised: Some either suggesting that conventional noise measures such as Leq did not adequately reflect lived experience of a series of aircraft noise events of greater intensity than the average noise level, or simply that insulation should extend further out geographically and take account of the increase in numbers of aircraft movements over the years.

Only one participant living in Hounslow (beside Heathrow on the dominant westerlies arrival path) was in an area covered by an insulation scheme (night noise scheme). The sound insulation work had been done before the person moved in, and when they tried to have further work done following the conversion of an attic, this was seen by the airport to be outside scheme provision as it was a new alternation. Ultimately, the participant paid for sound-insulated windows which have improved the situation but not fully remedied it.

All Heathrow participants understood the various sound insulation schemes once they were explained (they had been sent in advance an information sheet on the schemes for use during the interview) and the use of Lmax footprint for the night scheme was considered to be sensible. Overall progression of schemes was not readily evident, especially as the more recent QHS only covers a small number of properties. However, the $100 \%$ funding available under the QHS was seen as an improvement; although the $50 \%$ offer to pay towards insulation in other schemes was seen to be unfair-with participants querying why residents should have to pay to rectify a problem of the airport's making. Generally, interviewers had to work hard for any evaluative comments about sound insulation as an intervention, with participants feeling it was impossible to provide a view without speaking to those who had been in receipt. Nevertheless, some relevant comments were:

- Future airspace plans are more important.

- Respite is more of a contribution than insulation.

- Description feels technical.

- What's the performance of the insulation provision? (in terms of indoor sound level reduction).

- Offer needs to go further for different scenarios (i.e. consider each operational mode as you are exposed throughout the time when on a particular mode).

- Full costs coverage is a clear improvement. 
- Good use of money but other things are important.

- Would be concerned about contractors and quality of installation.

- Offer makes sense from a business perspective, it 'looks good'.

- Looks good on paper but what's the real impact?

- Can vulnerability be factored into the qualification for insulation?

In terms of land use planning around Heathrow, it is important to highlight that participants were generally happy to acknowledge the economic benefits from living near to the airport, although personal accessibility was less of a perceived benefit. The interviews also raised the negative issues around people who are frequent fliers and wider environmental problems (carbon and emissions). There was universal agreement that noise disbenefits outweighed any positive contribution from the airport to local communities. Much of this conversation was overlaid with concerns about the airport's expansion through a third runway: the government decision in favour of which was seen to be misplaced, leading to much criticism of named politicians and processes of decision-making, with communities being 'treated with total contempt'.

The participants described very little direct information from the airport and what little there may have been as tokenistic, leaving people with a feeling of no control. Some had participated in consultations which they felt had had some influence (e.g. over departures after $11.30 \mathrm{pm}$ ) but momentum seemed to have waned.

There was a desire to be consulted but there were also fears that the airport would control the agenda and, thus, outcomes. There was clearly room for improvement in communication over how engagement processes can be enhanced to allow for influence over things that currently feel out of control.

\section{Discussion}

Despite being leading airports, current sound insulation schemes at Marseille and Heathrow are not directly designed to target and improve residents' quality of life. Instead, they would appear to be part of a suite of noise management tools whose effectiveness in deployment is generally unchallenged by the airport and not sufficiently finessed to meet the needs of local people, when asked about what they would value. In attempting to evaluate the impact of these interventions after the fact, it was clear that this is near impossible as perceptions of appropriateness and impact are overlaid by wider perceptions of the operation/performance of the airport and indeed its development plans.

In addition, it is important to highlight that those insulation schemes that have been implemented have not been systematically evaluated. This can lead to repeated implementation of the same intervention in different contexts and/or continuation of interventions that may not be successful and may not result in the desired outcomes. This is an important consideration in respect to land use planning: without effective evaluation, it is impossible to ascertain whether an insulation scheme is of value to the individuals who are in receipt of the intervention. It is, then, likely to be equally 
unfeasible to establish whether a community vulnerable to encroachment would find value from airport provision of such sound insulation schemes.

Examining the results for the two airports further highlights that there is a high level of variation in available funds for insulation schemes across nations. Thus, conflicting policies and funding models can make comparison of schemes difficult and confusing.

It is also notable that the results from Marseille and Heathrow Airports show different impacts of sound insulation schemes on residents' quality of life. For example, depending on climate conditions of a region, sound insulation schemes can greatly differ across airports and national boundaries with respect to their impact on people's lives.

\section{Conclusions}

Sound insulation interventions have received substantial coverage in the academic and grey literature. However, with no evaluation of the types of schemes, it is challenging to determine best practice or potential for national experience to be globally applicable. Nevertheless, the results show better management approaches may help to more directly address the needs of local communities. Within this context, evaluation of a sound insulation scheme is essential, especially as such an intervention may not lead to the airport's desired outcome or may have potential unintended side effects. By evaluating an intervention, such undesirable impacts can be identified on a timely basis, addressed and the intervention improved accordingly. This form of evaluation can lead to the development of best practice for use of sound insulation in the context of land use planning. To contribute to a more holistic offer, which includes effective evaluation, it is also important to foster effective communication and open dialogue between an airport and its surrounding communities. Such steps can help towards successful sound interventions that are fair and of value to residents.

\section{Overall Discussion}

The LUP cases presented above highlight the central importance of enhanced engagement with stakeholders to inform specific interventions. In the case of preventative measures such improvement are needed to ensure coordination between competing land uses and sufficient consideration of future change in planning provisions by all authorities with planning responsibilities. In the case of mitigation measures, engaging with noise affected communities allows a better understanding of'what success looks like' such that measures can be nuance to more directly address issues of concern to local communities and thereby providing more optimised social outcomes valued by those same communities. 
With respect to mitigation measures, evaluation of interventions seems to be an important, and as yet, over-looked, contributor to learning about land use planning solutions. A brief review of regulatory and policy guidance on aircraft noise [6] revealed considerable variability in the provision of mitigation measures across the globe. Consequently, there is little standardisation in these areas, which makes tasks such as benchmarking very difficult as quantitative measures of performance have yet to be agreed upon across the airport sector. Further, the range of possible actions and the need to tailor mitigation provisions to local needs means that actions that are perceived to be generous and effective in one location may not receive the same response at another airport. Indeed, any ultimate indicator of the effectiveness of these actions (e.g. responses to community outreach, number of noise complaints, etc.) will be the result of a number of other inputs such as the success of communication strategies more generally and the effectiveness of attempts to manage aircraft noise at source.

Experience suggests that if genuine evaluation of specific interventions is to be attempted going forward, it needs to be built into the process of intervention design, decision-making and implementation. In other words, if the criteria for judging the success of an intervention are agreed from the outset along with the means (e.g. metrics) to monitor and assess achievement against these success criteria, then evaluation processes can at least determine whether the original agreed outcomes have been achieved and, indeed, contribute to any amendment if changes are needed to better address agreed outcomes. Demonstrating such progress with a series of interventions overtime could contribute to more positive airport-community relationships and thus potentially improve some of those non-acoustic factors (e.g. attitude, trust, perception of control) known to exacerbate annoyance.

When utilising planning powers to prevent noise problems around airports, experience points to the importance of coordinated engagement and action by those authorities with planning responsibilities if the future development of airports is to be acknowledged in spatial development plans and thereby constraints, arising from environmental impacts such as noise intrusion, minimised. The EU is championing such approaches through the advocacy of SUMPs ${ }^{4}$ (Sustainable Urban Mobility Plans) which provide a welcome addition to the land use toolkit. This approach focuses on the involvement of citizens and stakeholders, the coordination of policies between sectors (especially transport, land use, environment, development, energy, safety, social and health) and wide-ranging cooperation across different layers of government. Involvement of private actors is also considered to be relevant.

SUMPs highlight the need to cover all aspects of mobility (both people and goods), transport modes and associated services in an integrated manner. A plan is designed for the entire "functional urban area", as opposed to a single municipality within its administrative limits. Linking an airport to the neighbouring city or region will involve an integrated land use plan in sustainable urban/regional transport planning, combining measures from different sectors and underlying gaps, conflicts and priorities in a harmonised way.

${ }^{4}$ Mobility Strategy I Mobility and Transport (europa.eu). 
The sustainable development concept provides a prescriptive framework for selfgoverning parties to negotiate and settle differences concerning economic, social and ecological interests over the use of land in a spirit of partnership. The inclusion of airports in this framework addresses the existing 'lack of interest in dialogue' gap between parties concerned in LUP around airports.

Thus, SUMPs are valid, available instruments that provide a framework to help diminish/eliminate the challenges around LUP and airport development. Such an approach to an airport-city concept will solve several existing conflicts, as the planning process to develop a metropolitan area will have to consider the sustainability aspects of wider urban mobility, including connectivity to the airport and aspects of noise impact and air quality. Aviation impact would be considered with other integrated transport impacts, that is, the noise from aircraft would be integrated with road and rail noise and the aspects of community wellbeing would be reflected in a holistic manner.

\section{Conclusions}

The research previously described suggests that the biggest challenge to land use planning is a history of planning of land use around airports characterised by existing gaps and barriers. It is clear that there is a need to reverse previous poor practice. The examples provided highlight how some airports, local and National governments and other stakeholders have worked together on land use planning, which is more holistic and sensitive to economic, social and environmental needs. Nevertheless, there is still a need for wider stakeholder engagement if LUP options are to be aligned with community interests and thus optimise the social return on investment in LUP interventions.

The research suggested that there was a need for common strategy and sensitive local implementation. While the US can adjust planning processes at a state level, EU planning systems do not afford the flexibility to accommodate for such modification. However, the call for proactive, preventative approaches to systematic land use planning appears to be being answered in the EU through SUMPs. ${ }^{5}$ Better integration and more strategic approaches within the context of SUMPs hold value for prevention of encroachment and modifying noise impacts downwards.

Experience suggests that harmonised planning is preventative and, thus, preferable as airports develop. However, there remains a role for reactive approaches which, while they do offer some opportunity for mitigation clearly, have not been complemented by evaluation. Such evaluation would allow learning to be taken forward to the planning and development of more nuanced and tailored interventions. And, if implemented properly, provide an evidence base of the delivery on agreed outcomes

\footnotetext{
${ }^{5}$ More information available @ https://ec.europa.eu/transport/themes/urban/urban-mobility/ urban-mobility-actions/sustainable-urban_en).
} 
valued by, and agreed with, communities. Thereby, helping to build better airportcommunity relationships through actions that have demonstratively addressed local needs and experience.

Finally, looking forwards, new ways of understanding personal mobility can contribute to greater knowledge of how space is used in communities and how the experience of noise changes with movements around airport areas. The ANIMA project has looked at extending knowledge of personal mobility and aircraft noise distribution through two studies:

- one using dynamic mapping of noise around airports that uses people's daily travel patterns to determine where they are at a particular time and how their noise exposure changes over a day and,

- the other, looking at the usability of a specially developed online application to gain a greater understanding of the influence of the sound and visual environment on quality of life in airport regions. Using such techniques holds promise for a better understanding of the noise impacts which land use planning seeks to address.

\section{References}

1. Aeroport-iasi.ro. (2021) Aeroportul International Iași Romania. Available at: https://www.aer oport-iasi.ro/informatii-pasageri ("Info pasageri"/ "Destinatii"). Accessed 30 March 2021

2. Aeroport-iasi.ro. n.d. IASI AIRPORT_Detalii tehnice. Available at: https://www.aeroport-iasi. ro:5000/docs/download/Iasi-Airport-Date-tehnice.pdf. Accessed 30 March 2021

3. Aeroport-iasi.ro. n.d. AEROPORTUL IASI-Date demografice. Available at: https://www. aeroport-iasi.ro:5000/docs/download/Iasi-Airport-Date-Demografice.pdf. Accessed 30 March 2021

4. Aisro.ro. (2020) AIS ROMANIA. Available at: https://www.aisro.ro/ ("Publications"/ "AIP"/ "AIP"/ "AD"/ "AD 1 Aerodromes/ Heliports Introduction"/ "AD 1.1 Aerodrome availability"/ "AD 1.1-3 08 NOV 2018"/ "6.1. Noise abatement departure procedures"). Accessed 30 March 2021

5. Aisro.ro (2020) AIS ROMANIA. Available at: https://www.aisro.ro/ ("Publications"/ "AIP"/ "AIP"/ "AD"/ "AD 2 Aerodromes"/ "AD 2.10 LRIA IASI / Iasi"/ "AD 2.02 LRIA Aerodrome geographical and administrative data"). Accessed 30 March 2021

6. CATE (2009) Benchmarking BAA's Aircraft Noise Mitigation and Compensation Provisions. Internal Report. Manchester, CATE.

7. DfT (2003) The future of air transport. Department for Transport, London

8. Eur-lex.europa.eu (2002) Directive 2002/49/Ec of the European Parliament and of the CounciL of 25 June 2002 relating to the assessment and management of environmental noise. Available at: https://eur-lex.europa.eu/legal-content/EN/TXT/PDF/?uri=CELEX:320 02L0049\&qid=1617070253212\&from=EN. Accessed 30 March 2021

9. Eur-lex.europa.eu (2002) DIRECTIVE 2002/30/EC OF THE EUROPEAN PARLIAMENT AND OF THE COUNCIL of 26 March 2002 on the establishment of rules and procedures with regard to the introduction of noise-related operating restrictions at Community airports. Available at: https://eur-lex.europa.eu/legal-content/EN/TXT/PDF/?uri=CELEX:32002L0030\&fro $\mathrm{m}=\mathrm{EN}$. Accessed 30 March 2021

10. Facebook.com (2018) IASI Airport. Available at: https://www.facebook.com/IASIairport/pho tos/a.2005486159536463/2005498689535210/. Accessed 30 March 2021 
11. Freestone R, Baker D (2010) Challenges in land use planning around Australian airports. J Air Transp Manag 16:264-271

12. Haubrich J, Burtea N, Flindell I, Hooper P, Hudson R, Rajé F, Radulescu D, Schreckenberg D (2018) Recommendations on annoyance mitigation and implications for communication and end engagement. ANIMA Project Report D2.4. https://zenodo.org/record/2616668\#.YGRvai 1Q3s0. Accessed 31 Mar 2021

13. Heyes G, Dimitriu D, Hooper PD (2018a) Noise impact mitigation priorities report, ANIMA Project report D2.2. https://explore.openaire.eu/search/publication?pid=10.5281\% 252Fzenodo.2578805. Accessed 23 Mar 2021]

14. Heyes G, Dimitriu D, Hooper PD (2018b) Pan-European overview of existing knowledge and implementation of noise reduction strategies, ANIMA Project Report D2.1. https://explore.ope naire.eu/search/publication?pid=10.5281\%252Fzenodo.2578793. Accessed 23 Mar 2021

15. Heyes G, Galatioto F (2019) ANIMA D2.5 - Critical review of Balanced Approach Implementation across EU Member States. Zenodo. https://doi.org/10.5281/zenodo.3146128

16. Heyes G, Burtea N, Dimitriu D, Hooper P (2020) Recommendations for the implementation of the exemplification case studies, ANIMA Project Report D2.9. https://zenodo.org/record/463 9650\#.YGWUXS1Q2qA. Accessed 31 Mar 2021

17. ICAO (n.d.) live web page-balanced Approach to Aircraft Noise Management. Available at: https://www.icao.int/environmental-protection/Pages/noise.aspx. Accessed 23 Mar 2021

18. Iasi Airport. 2021. Encroachment, flight paths and evolution of aircraft movements. [email].

19. Institutul National de Statistica (2016) Transportul Aeroportuar De Pasageri Si Marfuri, Anul 2015. Available at: https://insse.ro/cms/sites/default/files/field/publicatii/transportul_aer oportuar_de_pasageri_si_marfuri_2015.pdf. Accessed 30 March 2021

20. Institutul national de statistica (2017) Transportul aeroportuar de pasageri si marfuri, anul 2016. Available at: https://insse.ro/cms/sites/default/files/field/publicatii/transportul_aeropo rtuar_de_pasageri_si_marfuri_in_anul_2016.pdf. Accessed 30 March 2021

21. Institutul National de Statistica (2018) Transportul aeroportuar de pasageri si marfuri, anul 2017. Available at: https://insse.ro/cms/sites/default/files/field/publicatii/transportul_aeropo rtuar_de_pasageri_si_marfuri_in_anul_2017.pdf. Accessed 30 March 2021

22. Institutul National De Statistica. 2019. Transportul Aeroportuar De Pasageri Si Marfuri, Anul 2018. Available at: https://insse.ro/cms/sites/default/files/field/publicatii/transportul_aer oportuar_de_pasageri_si_marfuri_in_anul_2018.pdf. Accessed 30 March 2021

23. Institutul National de Statistica (2020) Transportul Aeroportuar De Pasageri Si Marfuri, Anul 2019. Available at: https://insse.ro/cms/sites/default/files/field/publicatii/transportul_aer oportuar_de_pasageri_si_marfuri_in_anul_2019.pdf. Accessed 30 March 2021

24. Institutul National De Statistica (2021) Transportul Aeroportuar De Pasageri Si Marfuri, Anul 2020. Available at: https://insse.ro/cms/sites/default/files/field/publicatii/transportul_aer oportuar_de_pasageri_si_marfuri_in_anul_2020_0.pdf. Accessed 30 March 2021

25. iso.org (2003) ISO/TS 15666:2003. Available at: https://www.iso.org/standard/28630.html. Accessed 30 March 2021

26. Kuhlmann J, Rajé F, Richard I, Ohlenforst B (2020) Evaluations of previous interventions in improving quality of life, ANIMA Project Report D3.6. Accessed 23 Mar 2021

27. Legislatie.just.ro (2020) ORDIN nr. 318 din 25 februarie 2020. Available at: http://legislatie. just.ro/Public/DetaliiDocument/223521. Accessed 30 March 2021

28. Legislatie.just.ro (2020) CODUL AERIAN din 18 martie 2020. Available at: http://legislatie. just.ro/Public/DetaliiDocument/223897. Accessed 30 March 2021

29. Legislatie.just.ro (2019) LEGE nr. 121 din 3 iulie 2019. Available at: http://legislatie.just.ro/ Public/DetaliiDocument/216510. Accessed 30 March 2021

30. Legislatie.just.ro (2018) HOTARARE nr. 639 din 23 august 2018. Available at: http://legisl atie.just.ro/Public/DetaliiDocument/204347. Accessed 30 March 2021

31. Legislatie.just.ro (2016) HOTARARE nr. 944 din 15 decembrie 2016. Available at: http://leg islatie.just.ro/Public/DetaliiDocument/185147. Accessed 30 March 2021

32. Legislatie.just.ro (2013) HOTARARE nr. 1.260 din 12 decembrie 2012. Available at: http://leg islatie.just.ro/Public/DetaliiDocument/144470. Accessed 30 March 2021 
33. Legislatie.just.ro (2007) HOTARARE nr. 674 din 28 iunie 2007. Available at: http://legislatie. just.ro/Public/DetaliiDocumentAfis/83733. Accessed 30 March 2021

34. Legislatie.just.ro (2005) HOTARARE nr. 321 din 14 aprilie 2005. Available at: http://legisl atie.just.ro/Public/DetaliiDocumentAfis/61215. Accessed 30 March 2021

35. Legislatie.just.ro (2002) Regulamentul General De Urbanism din 27 iunie 1996 (republicat). Available at: http://legislatie.just.ro/Public/DetaliiDocument/40188. Accessed 30 March 2021

36. McLeod I, Latimore M (2014) Challenges in producing an Australian noise exposure forecast. InterNoise 2014, Melbourne, Australia, 16-19 November

37. TO70 (2018) Review of Perth Airport New Runway Project-Preliminary Draft Major Development Plan. T070 Aviation Australia for City of Canning, North Melbourne, Australia

38. UK Civil Aviation Authority (CAA) (2014) CAP 1165 Managing Aviation Noise, CAA. https:// publicapps.caa.co.uk/modalapplication.aspx ?appid=11\&mode=detail\&id=6251. Accessed 23 Mar 2021

39. Who.int (1997) WHOQOL Measuring Quality of Life. Available at: https://www.who.int/men tal_health/media/68.pdf. Accessed 30 March 2021

Open Access This chapter is licensed under the terms of the Creative Commons Attribution 4.0 International License (http://creativecommons.org/licenses/by/4.0/), which permits use, sharing, adaptation, distribution and reproduction in any medium or format, as long as you give appropriate credit to the original author(s) and the source, provide a link to the Creative Commons license and indicate if changes were made.

The images or other third party material in this chapter are included in the chapter's Creative Commons license, unless indicated otherwise in a credit line to the material. If material is not included in the chapter's Creative Commons license and your intended use is not permitted by statutory regulation or exceeds the permitted use, you will need to obtain permission directly from the copyright holder.

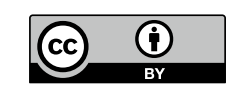

